\title{
THE THREAT OF LAW: REGULATORY BLACKMAIL OR AN ANSWER TO CONGRESSIONAL INACTION?
}

\author{
Rachelle Holmes Perkins*
}

\section{INTRODUCTION}

The administrative state has become an increasingly dominant force in American jurisprudence, at times wielding its power even beyond the reach of judicial and legislative control. ${ }^{1}$ Notwithstanding the fact that many legal scholars, regulated entities, and politicians have lamented the expanding role of the administrative state, regulatory agencies are more frequently flexing their newly acquired muscle and acting in contravention to traditional notions of checks and balances and delegatory norms. ${ }^{2}$

In this Article, I will examine an administrative law phenomenon I term the "threat of law," whereby an administrative agency unilaterally imposes its regulatory will on regulated entities on the boundaries of, or even outside of, the traditional rulemaking process. This "threat of law" goes beyond the idea of "agency threats" first examined by Tim $\mathrm{Wu}$ in

\footnotetext{
* Associate Professor of Law, George Mason University Antonin Scalia Law School. The author would like to thank Ross Davies for his insightful comments. The author would also like to thank the participants of the Robert A. Levy Fellows Workshop in Law \& Liberty for their helpful feedback. Research assistance from Kelli Cacciotti is gratefully acknowledged.

1. See, e.g., Susan E. Dudley, Improving Regulatory Accountability: Lessons from the Past and Prospects for the Future, 65 CASE W. RES. L. REV. 1027 (2015); David Casazza, Liberty Requires Accountability: Checking Delegations to Independent Agencies, 38 HARV. J.L. \& PUB. POL'Y 729 (2015).

2. See, e.g., Michael S. Greve \& Ashley C. Parrish, Administrative Law Without Congress, 22 Geo. MASON L. ReV. 501 (2015); Daniel A. Farber \& Anne Joseph O'Connell, The Lost World of Administrative Law, 92 TEX. L. REV. 1137 (2014); David Freeman Engstrom, Agencies as Litigation Gatekeepers, 123 YALE L.J. 616 (2013); Lars Noah, Governance by the Backdoor: Administrative Law(lessness?) at the FDA, 93 NEB. L. REV. 89, 129 (2014).
} 
his 2011 Duke Law Journal essay. ${ }^{3} \mathrm{Wu}$, in examining, and ultimately defending the use of "agency threats," specifically includes "warning letters, official speeches, interpretations, and private meetings with regulated parties." 4 However, he emphasizes that "agency threats" are "similar but not identical to the statutory category of "interpretative rules." " As analyzed herein, the "threat of law" goes a step further than an "agency threat" and contemplates situations in which the regulatory body in fact does issue regulations. ${ }^{6}$ However, these regulations are grounded in dubious statutory authority and can leave regulated entities with the non-ideal options of complying with the disputable regulations, facing penalties and litigation, or fighting a protracted and expensive court battle to get the regulations overturned.

Although I believe that an active "threat of law" can have implications in the regulatory world beyond the field of tax law, ${ }^{7}$ in order to illustrate the tangible pressure this threat of law can inflict on affected regulatees, this Article will focus on recent actions taken by the U.S. Department of the Treasury ("Treasury") in response to the growing tide of corporate tax inversion transactions. During the last four years the U.S. tax system has experienced a flurry of corporate inversion transactions, whereby U.S. based multinational corporations "invert" by replacing their former U.S. parent with a foreign corporation, typically located in a low-tax jurisdiction, while making otherwise minimal changes to their actual day-to-day operations. ${ }^{8}$ The overall impact of an

3. Tim Wu, Agency Threats, 60 Duke L.J. 1841, 1841-42 (2011). See also Brigham Daniels, When Agencies Go Nuclear: A Game Theoretic Approach to the Biggest Sticks in an Agency's Arsenal, 80 GeO. WASH. L. ReV. 442, 473 (2012); Jerry Brito, "Agency Threats" and the Rule of Law: An Offer You Can't Refuse, 37 HARV. J.L. \& PUB. POL'Y 553 (2014); Lars Noah, Administrative Arm-Twisting in the Shadow of Congressional Delegations of Authority, 1997 WIS. L. REV. 873, 874 (1997) (examining threats "by an agency to impose a sanction or withhold a benefit in hopes of encouraging 'voluntary' compliance with a request").

4. Wu, supra note 3 , at 1844 .

5. Id. at 1843-44. Indeed he states: "Threats are, by their nature, just that: threats to enforce or enact a rule, not binding actions in the usual sense of that word." Id. at 1843.

6. In fact, in rapidly changing areas of law, $\mathrm{Wu}$ argues that using informal agency threats is a superior tactic than engaging in formal rulemaking because it "forces the agencies to make law likely to last a long time based on poorly developed facts, and it invites long periods of uncertainty created by the judicial review process." Id. at 1842 .

7. There are, however, significant and unique tax-specific factors regarding the issuance and challenge of tax guidance and regulations that impact the specific overall effect of a threat of law on taxpayers. See infra Parts III and IV.

8. Typically this structure allows corporations to significantly reduce their overall effective tax rate. The United States still has the highest statutory corporate tax rate of the OECD countries at thirty-five percent, and the third highest overall marginal corporate tax rate in the world ("exceeded only by Chad and the United Arab Emirates"). See Kyle Pomerleau, Corporate Income Tax Rates around the World, 2015, TAX FOUND. (Oct. 1, 2015), http://taxfoundation.org/article/corporate- 
inversion transaction is that it makes it easier for U.S. corporations to limit or avoid U.S. taxation on their worldwide earnings, while keeping the bulk of their operations in the United States. ${ }^{9}$

By early 2014, the White House and certain members of Congress were making increasingly forceful statements against these transactions, which were believed to create a significant and immediate threat to the U.S. fisc. President Obama made several speeches condemning corporate inversion transactions as violating "economic patriotism," and began to put pressure on Congress and Treasury to take action. ${ }^{10}$

On July 15, 2014, Treasury Secretary Jacob Lew sent a letter to Congress, imploring them to pass legislation to curb "this abuse of our tax system" and to make any legislation retroactive to May 2014. ${ }^{11}$ Congress, however, was deadlocked and it was clear that it would be unable to pass any legislation in the foreseeable future. ${ }^{12}$ This stalemate

income-tax-rates-around-world-2015; OECD.Stat, ORGANISATION FOR ECONOMIC CO-OPERATION AND DEVELOPMENT (Nov. 21, 2016), http://stats.oecd.org//Index.aspx?QueryId=58204\#.

9. The United States is one of only a handful of countries that make domestic corporations pay tax at the domestic corporate tax rate, even on income earned from foreign subsidiaries located in low-tax jurisdictions. Even Canada and the United Kingdom only tax domestic profits. A successfully tax inverted corporation significantly reduces the amount of corporate tax revenues received by the U.S. fisc. Previously Congress passed I.R.C. section 7874 in the American Jobs Act of 2004, which was meant to prevent corporate tax inversions. However, in recent years, taxpayers have developed inversion transaction structures that effectively exploit loopholes in I.R.C. section 7874 .

10. See, e.g., Oliver Duggan, Barack Obama Attacks 'Corporate Deserters' in Tax Inversion Takeovers, THE TELEGRAPH (July 25, 2014, $2: 03 \quad$ PM), http://www.telegraph.co.uk/finance/10990994/Barack-Obama-attacks-corporate-deserters-in-taxinversion-takeovers.html. President Obama acknowledged that these companies are "basically taking advantage of tax provisions that are technically legal," but argued that "if you're doing business here, if you're basically still an American [company], but you're simply changing your mailing address to avoid paying taxes, then you're really not doing right by the country and by the American people." Interview by Steve Liesman with Barack Obama, President, United States, in Washington, D.C. (July 24, 2014), http://video.cnbc.com/gallery/?video=3000295639.

11. Letter from Jacob Lew, Sec'y of the Treasury, to Dave Camp, Chairman of the Comm. on Ways and Means, U.S. House of Representatives (July 15, 2014), http://im.ftstatic.com/content/images/89217f94-0ca4-11e4-943b-00144feabdc0.pdf. It is important to note that many taxpayers do not view inversions as abusive tax transactions. Rather, they are viewed as legitimate methods of achieving tax reductions on their worldwide operations. See, e.g., Diana Furchtgott-Roth, Tax Inversions Help, Not Hurt, the Economy, MARKET WATCH (Aug. 8, 2014, 7:20 AM), http://www.marketwatch.com/story/tax-inversions-help-not-hurt-the-economy-2014-08-08.

12. Stephen E. Shay, Mr. Secretary, Take the Tax Juice Out of Corporate Expatriations, 144 TAX Notes 473, 473 (2014) ("[I]n the current political environment there is little reason to believe that a statutory solution will be enacted.'); A'Dair Flynt, Notice 2014-52: The Treasury's Response to Corporate Tax Inversions, LA. L. REV. (Nov. 19, 2014), http://lawreview.law.lsu.edu/2014/11/19/notice-2014-52-the-treasurys-response-to-corporate-taxinversions/\#_ftn73; see generally Greve \& Parrish, supra note 2; see Kelly Drye Client Advisory, Tax Inversions: Administrative and Legislative Responses, KELLEY DRYE (Oct. 10, 2014), http://www.kelleydrye.com/publications/client_advisories/0930 ("Both ends of Pennsylvania Avenue reacted to the surge of inversions. Although legislative action is likely impossible this year 
in Congress left Treasury to attempt to curb the growing tide of inversion transactions. However, at a press conference on July 16, 2014, Secretary Lew publicly declared, "we [at Treasury] do not believe we have the authority to address this inversion question through administrative action" without help from Congress. ${ }^{13}$ In fact, many practitioners, taxpayers, and academics likewise questioned whether Treasury could unilaterally act to stop corporate inversion transactions under the existing statutory and regulatory framework. ${ }^{14}$

However, on July 29, 2014, former Treasury Deputy Assistant Secretary and Harvard Law School Professor Stephen Shay wrote an open letter to Secretary Lew in Tax Notes, a leading source of tax news for tax professionals, arguing that under his interpretation of the existing regulations, Treasury in fact could and should unilaterally issue regulations to stop inversion transactions. ${ }^{15}$ While it is unclear whether this letter by itself, or in combination with other factors finally pushed Secretary Lew to act, just two months after his own declaration that he was powerless to do so, Secretary Lew issued Notice 2014-52 (the "Inversion Notice"), ${ }^{16}$ outlining Treasury's intention to issue a broad set of anti-inversion regulations that would put an end to (or at least a damper on) corporate inversions.

Treasury's abrupt turnabout in position and issuance of the Inversion Notice outlining broad retroactive regulatory action sent discernable shockwaves through the corporate and broader tax community. Academics and practitioners debated and questioned whether Treasury acted outside of the bounds of its statutory authority. ${ }^{17}$ In fact, Kimberly

and uncertain next year, several Members of Congress have circulated concepts to stop tax inversions and protect the flow of revenue to the U.S. Treasury.").

13. Steven Russolillo, In Opposing Tax Inversions, Treasury's Lew Calls for 'Economic Patriotism', WALl ST. J. (July 16, 2014, 9:16 AM), http://blogs.wsj.com/moneybeat/2014/07/16/inopposing-tax-inversions-treasurys-lew-calls-for-economic-patriotism/.

14. See, e.g., Howard Gleckman, Treasury Secretary Jack Lew Says Anti-Inversion Decision Will Come Soon, URBAN WIRE (Sep. 8, 2014), http://www.urban.org/urban-wire/treasury-secretaryjack-lew-says-anti-inversion-decision-will-come-soon; Joseph B. Darby III, Inverted Priorities: Why the Proposed Treasury Rules Are Unlikely to Stop Inversion Transactions, THOMSON REUTERS TAX \& ACCT. http://www.sandw.com/assets/htmldocuments/Inverted\%20Priorities.\%20Darby\%20Article\%20B17 77290.PDF; Alex M. Parker, Executive Action on Inversions? Not So Fast., BLOOMBERG BNA INT’L TAX BLOG (Aug. 18, 2014), http://www.bna.com/executive-action-inversions-b17179893937/.

15. See Shay, supra note 12, at 473 ("[W] is at risk, doing nothing borders on the irresponsible.").

16. I.R.S. Notice 2014-52, 2014-42 I.R.B. 712.

17. Thomas Lys, who teaches corporate restructuring at Northwestern University's Kellogg School of Management, stated that "[i]t's a stretch of current regulations" for the Executive Branch to act unilaterally. Josh Lederman, Facing Logjam in Congress, Obama Seeks Steps to Curb Tax Breaks for Firms Moving Overseas, U.S. NEWS \& WORLD REPORT (Aug. 5, 2014, 7:11 PM), 
Blanchard, a leading tax practitioner, explicitly declared "if challenged in court, most of the rules in the [Inversion] Notice would not stand."18 Taxpayers directly affected by the Inversion Notice were left scratching their heads. ${ }^{19}$ Some were in the middle of inversion transactions that were not yet closed. ${ }^{20}$ Others were in serious discussions to consider inverting offshore. ${ }^{21}$ In fact, in October 2014, AbbVie, Inc. called off the largest proposed U.S. company inversion with U.K.-based Shire Plc., a $\$ 54.8$ billion transaction that was supposed to lower AbbVie's tax liability from twenty-two percent to thirteen percent. ${ }^{22}$ AbbVie agreed to pay a $\$ 1.635$ billion break-up fee to its rival Shire Plc. rather than move forward with the deal, and directly cited the Inversion Notice as the reason its board of directors withdrew support for the transaction. ${ }^{23}$

http://www.usnews.com/news/politics/articles/2014/08/05/obama-seeks-executive-ways-to-limit-taxinversions. But see Shay, supra note 12, at 473 ("One of the Treasury secretary's most important responsibilities is the health of the tax system under the laws adopted by Congress. Congress has given Treasury broad and in some cases sweeping authority to adopt regulations, including specific grants of authority that bear on issues at the heart of corporate inversions.").

18. Kimberly S. Blanchard, Would a Court Uphold the Application of Notice 2014-52 to Combinations Closed After September 21, 2014?, BlOOMBERG BNA (Apr. 10, 2015), http://www.weil.com/ /media/files/pdfs/would-a-court-uphold-the-application-of-notice201452.pdf.

19. See, e.g., John F. Darcy, Current Events in Federal Income Tax: Selected Regulations, Rulings and Cases at 73, 42ND ANNUAL VT. TAX SEMINAR 2014 RESOURCE GuIDE (last visited Jan. 26, 2016), http://www.vttaxseminar.org/documents/2014/RESOURCE\%20GUIDE.pdf ("The rules described in Notice 2014-52 reflect an expansive interpretation of section 7701(l)'s authority to address 'multiple-party financing transactions.' Integration of business operations is not commonly considered a 'financing transaction.' The recast described in Notice 2014-52 creates ambiguous and counter-intuitive results for what would normally be straightforward transactions. .. . Legislation enacted section 304(b)(5)(B) in 2010. The statute appears to require only $50 \%$ U.S. taxation on a targeted constructive dividend. Nevertheless, in Notice 2014-52, Treasury has interpreted its regulatory authority under the rule to allow it to further tighten the statutory rule.").

20. For instance, AbbVie, Inc., a North Chicago, Illinois-based pharmaceutical company had agreed to buy U.K.-based Shire Plc. for \$54 billion and Mylan Laboratories, a Pittsburgh, Pennsylvania-based pharmaceutical company had agreed to buy Abbott Laboratories' Netherlandsbased international generic business. Nathan Vardi, AbbVie to Buy Shire for $\$ 54$ Billion in Biggest Inversion Deal Ever, ForBES (July 18, 2014, 7:18 AM), http://www.forbes.com/sites/nathanvardi/2014/07/18/abbvie-to-buy-shire-for-54-billion-in-biggestinversion-deal-ever/.

21. Walgreen Co. was contemplating relocating to Switzerland. Paul Ziobro, Walgreen Weighs Riding Tax-Inversion Wave, WALL ST. J. (July 15, 2014, 7:21 PM), http:/www.wsj.com/articles/walgreen-weighs-riding-tax-inversion-wave-1405453698. Pfizer Inc. was still weighing inversion deals following its failed bid to invert by buying U.K.-based AstraZeneca Plc. in March 2014. Maureen Farrell, Pfizer CEO is Still Weighing Inversion Deals, WALL ST. J. (Sept. 12, 2014, 1:08 PM), http://blogs.wsj.com/moneybeat/2014/09/12/pfizer-ceo-isstill-weighing-inversion-deals/.

22. Simeon Bennett \& Caroline Chen, AbbVie Becomes Biggest U.S. Company To Move Domestic Address in $\$ 55$ Billion Deal, DAILY TAX REP. (BNA) NO. 139, at G-2 (July 18, 2014).

23. Josh Beckerman, AbbVie, Shire Terminate Year's Biggest Deal, WALl St. J. (Oct. 20, 2014, 6:27 PM), http://www.wsj.com/articles/abbvie-shire-terminate-what-was-years-biggest-deal1413841225 (AbbVie stated the Inversion Notice "reinterpreted long-standing tax principles in a 
AbbVie's chairman and CEO, Richard A. Gonzalez, declared "[t]he unprecedented unilateral action by the U.S. Department of Treasury may have destroyed the value in this transaction . ..."24 Salix Pharmaceutical also cancelled its proposed inversion transaction, claiming the Inversion Notice created "more uncertainty regarding the potential benefits we expected to achieve." 25

What, if anything, could these affected companies do to challenge this sweeping action by Treasury if indeed Treasury did overstep its regulatory authority? Unfortunately for them, the answer was very little other than to proceed at their own risk. This is true even in light of the Supreme Court's pronouncement in Mayo Foundation for Medical Education and Research et al. v. United States ${ }^{26}$ that tax and the Treasury are not special. This declaration by the Supreme Court purportedly ended the prior reign of so-called "tax exceptionalism," suggesting that tax regulations should be treated the same as regulations issued by any other administrative body. ${ }^{27}$ However, even in the shadow of Mayo, because of Treasury's explicit statutory grant to issue retroactive regulations, the broad protections against pre-enforcement judicial review afforded to it by statute, and the judicial deference it is afforded, successfully challenging Treasury's abuse of power remains an uphill, long, and expensive battle for taxpayers.

In light of the obstacles affected taxpayers are up against in the face of regulations of dubious authority, Treasury is able to wield what I term an effective "threat of law." While certainly less binding than an actual legitimately exercised "force of law," the effects (at least in the nearterm) can be identical. For example, with respect to the Inversion Notice, taxpayers could either comply with Treasury's Inversion Notice or potentially face a myriad of negative consequences. When faced with

uniquely selective manner designed specifically to destroy the financial benefits of these types of transactions.").

24. Associated Press, Shire Gets $\$ 1.64$ B Breakup Fee from AbbVie, CBS MoneYWatch (Oct. 20, 2014, 7:00 PM), http://www.cbsnews.com/news/shire-gets-1-64b-breakup-fee-from-abbvie/.

25. Are the new IRS Inversion Regulations in Notice 2014-52 Working?, SHERAYZEN LAW OfFICE PLLC (Nov. 9, 2014), http://sherayzenlaw.com/are-the-new-irs-inversion-regulations-innotice-2014-52-working/. Minnesota-based Medtronic still closed its deal to invert to Ireland, but significantly restructured its transaction as a result of the Inversion Notice, limiting some of the potential tax benefits. Rakesh Sharma, Medtronic Avoids U.S. Taxes While Saddling Shareholders With a Hefty Tax Bill, THE STREeT (Jan. 28, 2015, 6:01 AM), http://www.thestreet.com/story/13024863/2/medtronic-avoids-us-taxes-while-saddling-shareholderswith-a-hefty-tax-bill.html ("As a result of the notice, Medtronic, which had originally intended to finance the transaction using its $\$ 13.5$ billion cash reserves from earnings abroad, was forced to borrow $\$ 16$ billion.").

26. 562 U.S. $44,57-58$ (2011).

27. Kristin E. Hickman, Unpacking the Force of Law, 66 VAND. L. REV. 465, 466 (2013). 
these options, while some taxpayers rolled the proverbial dice and found ways to structure around the Inversion Notice, ${ }^{28}$ others declined to play this game of tax chicken with Treasury and called off their transactions. ${ }^{29}$

In this Article, I will explore the contours of this so-called "threat of law" that Treasury can employ even in the absence of legitimate congressional authority to do so. Part II of this Article gives a brief background of the history of the regulation of corporate inversions in the United States. Part III discusses Treasury's generally broad regulatory powers, including its ability to issue retroactive regulations. Part IV discusses the justiciability obstacles that taxpayers face in bringing suit against Treasury, including I.R.C. section 7421 and the Declaratory Judgment Act ("DJA"). ${ }^{30}$ It also discusses the impact of the Supreme Court's ruling in Mayo and the level of deference Treasury regulations are afforded. Part V then examines the implications that Treasury's regulatory powers, Chevron deference, and litigation standing safeguards have on its use of the threat of law. Specifically, it will explore the efficacy this threat of law can have on Treasury's ability to act swiftly in response to emerging tax challenges. Moreover, it will address the implications this threat has for Treasury's statutory retroactivity powers, traditional notions underlying Congress's perceived delegation of authority to Treasury, and to the justiciability protections these actions should be afforded. Part VI concludes.

\section{THE INVERSION GUIDANCE SAGA}

As mentioned above, a U.S.-based multinational corporation engages in a so-called "inversion" transaction by replacing its former U.S. parent with a foreign corporation, typically located in a low-tax jurisdiction, while making otherwise minimal changes to its actual day-to-day operations. $^{31}$ While many of the inverted companies continue to have a substantial continuing U.S. presence, the inverted structure makes it

28. The Medtronic deal still closed, albeit with revised terms. See Sharma, supra note 25 and accompanying text.

29. AbbVie, Inc. canceled its planned inversion at a cost of over $\$ 1$ billion. See supra notes 20-24 and accompanying text. See also infra notes 61-64 and accompanying text, describing how Pfizer and Allergan called off their proposed merger in light of the Inversion Regulations.

30. 28 U.S.C. $\$ 2201$ (2000).

31. Typically this structure allows corporations to significantly reduce their overall effective tax rate. The United States still has the highest statutory corporate tax rate of the OECD countries at 35 percent, and the third highest overall marginal corporate tax rate in the world (exceeded only by Chad and the United Arab Emirates). See Pomerleau, supra note 8. 
easier for the U.S. corporations to limit or avoid U.S. taxation on their worldwide earnings. ${ }^{32}$

Back in 2004 Treasury responded to an initial wave of inversions that took place in the early 2000 s by passing I.R.C. section $7874,{ }^{33}$ which specifically targets and penalizes these transactions. In particular, I.R.C. section 7874 disregards the inversion and continues to treat the new foreign parent as a U.S. corporation for tax purposes if a U.S.-based entity restructures such that the former U.S. parent is replaced by a foreign parent and (1) less than 25 percent of the new foreign entity's business activity "is in the home country of the new foreign parent," and "(2) the shareholders of the old U.S. parent end up owning at least [sixty] percent of the shares of the new foreign parent." 34 Inverted corporations that have a greater than sixty percent, but less than eighty percent, continuing ownership stake by the shareholders from the former U.S. parent are not treated as U.S. corporations, but are subject to other potentially adverse tax consequences. ${ }^{35}$ These consequences, however, are more avoidable and multinational corporations have readily exploited these loopholes.

Thus, although the existing I.R.C. section 7874 provisions effectively shut down inversions involving ownership levels of at least eighty percent, they have been ineffective in stopping inversions at lower ownership thresholds, and the current wave of inversions involves transactions with a continuing ownership interest under eighty percent. ${ }^{36}$ As Treasury has acknowledged: "Current law subjects inversions that appear to be based primarily on tax considerations to certain potentially adverse tax consequences, but it has become clear by the growing pace of these transactions that for many corporations, these consequences are acceptable in light of the potential benefits." twenty U.S.-based companies have inverted since 2012. ${ }^{38}$

32. See supra note 9 and accompanying text.

33. All section references herein are to the Internal Revenue Code of 1986, as amended, and the Treasury regulations issued thereunder.

34. Press Release, U.S. Dep't of the Treasury, Fact Sheet: Treasury Actions to Rein in Corporate Tax Inversions (Sept. 22, 2014) [hereinafter Fact Sheet], http://www.treasury.gov/presscenter/press-releases/Pages/j12645.aspx; I.R.C. § 7874(b); Treas. Reg. § 1.7874-3.

35. In particular, these entities will be taxed on any gain from their post-inversion transfer of assets. I.R.C. $\S \S 7874(a)(1),(d)(2)$.

36. Fact Sheet, supra note 34 .

37. $I d$.

38. Jeffrey McCracken, Pfizer to Terminate $\$ 160$ Billion Merger With Allergan, BLOOMBERG (Apr. 5, 2016, 8:24 PM), http://www.bloomberg.com/news/articles/2016-04-06/pfizer-allergan-planto-mutually-end-merger-cnbc-reports ("Since the first inversion in 1982, 53 U.S. companies have shifted their tax addresses offshore—22 of them since 2012."); Zachary Mider \& Jesse Drucker, Tax 
Treasury and Congress were under significant pressure from President Obama, the media, and prominent tax scholars to take immediate and decisive action to stop the surge of inversion activity. ${ }^{39}$ However, notwithstanding even a direct plea to Congress by Secretary Lew to pass legislation to end inversion transactions, Congress declined to do so. This is true even though both sides of the aisle publicly supported taking actions to curb these transactions. ${ }^{40}$

As discussed above, in the absence of congressional action, Treasury's initial response to the new flurry of inversion activity was to issue the Inversion Notice. Although Treasury itself acknowledged that the Inversion Notice was not a complete solution, it issued the notice in hopes that it would at least slow down the flow of inversion transactions. The Inversion Notice involved five different I.R.C. sections304(b)(5)(B), 367, 956(e), 770(1), and 7874-and was intended to attack two different aspects of inversion transactions.

First, the Inversion Notice outlined rules designed to attack preinversion tactical moves by treating more inverted companies as U.S. corporations. ${ }^{41}$ For instance, I.R.C. section 7874(b) clearly establishes an ownership percentage of eighty percent (i.e., at least eighty percent of the new foreign corporation is held by the former U.S. corporation shareholders) in order to treat the foreign acquirer as a U.S. corporation. Although Treasury clearly lacked the power to rewrite the specific eighty percent threshold written by Congress, it opted to instead exercise its purported regulatory powers to change what goes into the ownership fraction. By proposing rules to maximize what is included in the numerator and minimize what is included in denominator, the rules outlined in the Inversion Notice had the practical effect of decreasing the

Inversion: How U.S. Companies Buy Tax Breaks, BloOMBERG QUICK TAKe (Apr. 6, 2016, 5:15 PM), http://www.bloomberg.com/quicktake/tax-inversion; Donald J. Marples \& Jane G. Gravelle, Corporate Expatriation, Inversions, and Mergers: Tax Issues, CONG. RES. SERV. 2 (Apr. 27, 2016), http://fas.org/sgp/crs/misc/R43568.pdf.

39. See, e.g., Oliver Duggan, Barack Obama Attacks 'Corporate Deserters' in Tax Inversion Takeovers, TELEGRAPH (July 25, 2014, $2: 03$ PM), http://www.telegraph.co.uk/finance/10990994/Barack-Obama-attacks-corporate-deserters-in-taxinversion-takeovers.html. Even presidential candidates in the 2016 election from both sides of the aisle denounced corporate inversions. Hillary Clinton, Bernie Sanders, and Donald Trump all called for an end to the practice. See Jennifer Surane, Johnson Controls Merges With Tyco in TaxLowering Maneuver, BLOOMBERG MKTS. (Jan. 25, 2016, 6:07 AM), http://www.bloomberg.com/news/articles/2016-01-25/johnson-controls-to-combine-with-tyco-movedomicile-to-ireland.

40. Notwithstanding their agreement in principle, a large disparity in approach exists in how to deal with the inversion problem.

41. Specifically, they address pre-inversion tactical moves including cash-box techniques, skinny-down techniques, and spin-versions. See Fact Sheet, supra note 34. 
ownership percentage required by the existing statute. ${ }^{42}$ Second, the Inversion Notice took aim at post-inversion transactions intended to allow the newly inverted corporations to access foreign earnings without incurring additional U.S. taxes. ${ }^{43}$ Importantly, the Inversion Notice announced that once actual regulations were issued they would be retroactive to the date of the Inversion Notice, September 22, $2014 .^{44}$

The IRS issued a second inversion notice on November 19, 2015, announcing its intention to issue additional regulations targeting inversion transactions (the "Second Inversion Notice," and together with the "Inversion Notice," the "Inversion Notices"). In addition to making corrections and clarifications to some of the rules put forth in the Inversion Notice, the Second Inversion Notice announced additional guidance aimed at both limiting inversion transactions themselves ${ }^{45}$ and limiting post-inversion benefits. ${ }^{46}$

Most recently, in April and October 2016, Treasury issued regulations targeting inversion transactions (the "Inversion Regulations"). ${ }^{47}$ The Inversion Regulations are comprised of temporary regulations formalizing the rules set forth in the Inversion Notices, as

42. Kimberly S. Blanchard, Extensive New Anti-Inversion Rules Issued, 145 TAX NOTES 89 (Oct. 6, 2014), http://taxprof.typepad.com/files/145tn0089.pdf ("[The IRS] continued its pattern of stretching its regulatory authority to the limit—some would say beyond the limit — to reach as many transactions as possible by adopting rules to minimize the denominator and maximize the numerator of the ownership fraction, goosing the fraction upward.").

43. Specifically, they address techniques involving hopscotch loans, de-controlling strategies, and the repatriation of trapped cash. See Fact Sheet, supra note 34. It is estimated that U.S. corporations have parked as much as $\$ 2$ trillion in cash overseas. Julie Hirschfeld Davis, White House Weighs Actions to Deter Overseas Tax Flight, N.Y. TiMES (Aug. 5, 2014), http://www.nytimes.com/2014/08/06/business/Action-in-washington-on-corporate-inversions.html.

44. I.R.S. Notice 2014-52, 2014-42 I.R.B. 712.

45. Specifically, the IRS will target abusive inversion transactions by "(i) requiring the foreign acquiring corporation to be subject to tax as a resident of the relevant foreign country in order to have substantial business activities in the relevant foreign country; (ii) disregarding certain stock of the foreign acquiring corporation in 'third-country' transactions; and (iii) clarifying the definition of nonqualified property for purposes of disregarding certain stock of the foreign acquiring corporation." I.R.S. Notice 2015-79, 2015-49 I.R.B. 775.

46. Treasury intends to address post-inversion transactions by "(i) defining inversion gain for purposes of section 7874 to include certain income or gain recognized by an expatriated entity from an indirect transfer or license of property and providing for aggregate treatment of certain transfers or licenses of property by foreign partnerships for purposes of determining inversion gain; and (ii) requiring an exchanging shareholder to recognize all of the gain realized upon an exchange of stock of a controlled foreign corporation. ..." Id.

47. Temp. Treas. Reg. $\S \S 1.304-7 \mathrm{~T}(\mathrm{e}), 1.367(\mathrm{a})-3 \mathrm{~T}(\mathrm{c})(11)(\mathrm{ii}), 1.367(\mathrm{~b})-4 \mathrm{~T}(\mathrm{~h}), 1.956-2 \mathrm{~T}(\mathrm{i})$, 1.7701(l)-4T(h), 1.7874-1T(h)(2), 1.7874-2T(l)(2), 1.7874-3T(f)(2), 1.7874-4T(k)(1), 1.7874-6T(h), 1.7874-7T(h), $1.7874-8 \mathrm{~T}(\mathrm{i}), \quad 1.7874-9 \mathrm{~T}(\mathrm{~g}), \quad 1.7874-10 \mathrm{~T}(\mathrm{i}), \quad 1.7874-11 \mathrm{~T}(\mathrm{f}), \quad 1.7874-12 \mathrm{~T}(\mathrm{~b})$ (as amended by T.D. 9761, 81 Fed. Reg. 20857); Prop. Treas. Reg. 108060-15, 2016-17 I.R.B. 636, 63681 Fed. Reg. 20588 (Apr. 25, 2016). 
well as additional rules not covered in the Inversion Notices. ${ }^{48}$ Moreover, as promised in the Second Inversion Notice, ${ }^{49}$ Treasury issued proposed regulations targeting one of the primary post-inversion benefits of inversion transactions-earnings stripping. ${ }^{50}$ Congressional hearings were held regarding the proposed earnings stripping regulations in July $2016,{ }^{51}$ and members of the House Ways and Means Committee even urged Treasury not to finalize the regulations without further review, arguing that they could "have a significant adverse impact on the American economy, discouraging investment and hurting American jobs and workers. ${ }^{, 52}$ Undeterred, a few weeks later, Treasury finalized a more tailored version of the regulations in October 2016. ${ }^{53}$ Earnings stripping is an important post-inversion technique because even after an inversion, a U.S. corporation's U.S.-based businesses are still taxed by the United States at U.S. tax rates. In an attempt to lower the taxes still

48. Temp. Treas. Reg. $\S \S 1.304-7 \mathrm{~T}(\mathrm{e}), 1.367(\mathrm{a})-3 \mathrm{~T}(\mathrm{c})(11)(\mathrm{ii}), 1.367(\mathrm{~b})-4 \mathrm{~T}(\mathrm{~h}), 1.956-2 \mathrm{~T}(\mathrm{i})$, 1.7701(l)-4T(h), 1.7874-1T(h)(2), 1.7874-2T(l)(2), 1.7874-3T(f)(2), 1.7874-4T(k)(1), 1.7874-6T(h), $1.7874-7 \mathrm{~T}(\mathrm{~h}), \quad 1.7874-8 \mathrm{~T}(\mathrm{i}), \quad 1.7874-9 \mathrm{~T}(\mathrm{~g}), \quad 1.7874-10 \mathrm{~T}(\mathrm{i}), \quad 1.7874-11 \mathrm{~T}(\mathrm{f}), \quad 1.7874-12 \mathrm{~T}(\mathrm{~b}) \quad$ (as amended by T.D. 9761,81 Fed. Reg. 20857).

49. I.R.S. Notice 2015-79, 2015-49 I.R.B. 784 ("The Treasury Department and the IRS expect to issue additional guidance to further limit (i) inversion transactions that are contrary to the purposes of section 7874 and (ii) the benefits of post-inversion tax avoidance transactions. In particular, as described in section 5 of Notice 2014-52, the Treasury Department and the IRS continue to consider guidance to address strategies that avoid U.S. tax on U.S. operations by shifting or 'stripping' U.S.-source earnings to lower-tax jurisdictions, including through intercompany debt. Accordingly, the Treasury Department and the IRS reiterate the requests for comments made in Notice 2014-52.").

50. Prop. Treas. Reg. $\S \S 1.304-7,1.367$ (a)-3, 1.367(b)-4, 1.956-2, 1.7701(1)-4, 1.7874-1, $1.7874-2,1.7874-3,1.7874-4,1.7874-6,1.7874-7,1.7874-8,1.7874-9,1.7874-10,1.7874-11$, 1.7874-12, 81 Fed. Reg. 20588 (Apr. 8, 2016). Treasury and academic scholars have both conducted studies analyzing the extensive impact that earnings stripping can have on inverted entities. See U.S. Dep't Treas., Report to The Congress on Earnings Stripping, Transfer Pricing and U.S. Income Tax Treaties (Nov. 2007); Jim Seida \& William Wempe, Effective Tax Rate Changes and Earnings Stripping Following Corporate Inversion, 57 NAT'L TAX J. 805 (2004) (studying twelve corporate inversions and finding that earnings stripping was the primary mechanism to reduce tax liability). See also Steven Solomon, Corporate Inversions Aren't the Half of It, N.Y. TIMES (Feb. 9, 2016), http://www.nytimes.com/2016/02/10/business/dealbook/corporate-inversions-arent-the-half-ofit.html (" $[\mathrm{T}]$ he bulk of the benefits of an inversion may come not from the lower foreign tax rate but from substantially reducing taxes on the American subsidiary [through earnings stripping].").

51. IRS, Treatment of a Certain Interests in Corporations as Stock or Indebtedness; Hearing, FEDERAL REGISTER (July 14, 2016), https://www.federalregister.gov/documents/2016/06/21/201614734/treatment-of-a-certain-interests-in-corporations-as-stock-or-indebtedness-hearing.

52. See David Morgan, Republicans Asked U.S. Administration Not to Finalize Inversion Rules, REUTERS BUS. NEwS (Oct. 5, 2016, 1:51 PM), http://www.reuters.com/article/us-usa-taxinversions-idUSKCN12525R.

53. Prop. Treas. Reg. §§ 1.385-3, 1.385-4, 1.752-2, 81 Fed. Reg. 72858 (Oct. 21, 2016). See Richard Rubin, Treasury Announces Final Regulations on Earnings Stripping, WALL ST. J. (Oct. 13, 2016, 6:40 PM), http://www.wsj.com/articles/treasury-announces-final-regulations-on-earningsstripping-1476392428. 
owed to the United States, the existing U.S. business units of the inverted corporation borrow large amounts of money from their now-foreign parent. Under pre-existing U.S. tax laws, the U.S. subsidiaries could take deductions for the interest paid to the foreign parents, thereby reducing their U.S. tax liability. The Inversion Regulations are more far reaching than most had anticipated, and practitioners and corporations alike have lamented their overbroad application and dubious statutory authority. ${ }^{54}$

Nevertheless, the Inversion Regulations still pose a substantial, although not insurmountable, roadblock for companies still considering moving their tax headquarters out of the United States. ${ }^{55}$ The Kelley Drye \& Warren LLP announcement regarding the initial Inversion Notice described the effect as follows:

Treasury clearly has put a monkey wrench in plans no matter how much the companies involved may argue to the contrary. It is simply not possible to blindly stick with plans in light of Treasury's announced intention to find key elements of these planned mergers as illegitimate tax dodges. In the end, it may be that the companies involved are still able to restructure plans and proceed with planned tax inversions perhaps preparing years of litigation with U.S. tax authorities, but the risks and uncertainties for pursuing tax inversions have clearly been raised and that will eventually impact business planning. ${ }^{56}$

In addition to having to execute a transaction imbued with significant uncertainties as to whether tax benefits will be able to be realized, taxpayers that chose not to comply with the Inversion Notices or choose not to comply with the Inversion Regulations may be subject to I.R.C. section 6662 understatement penalties. ${ }^{57}$ Moreover, taxpayers likely will not be able to challenge the legitimacy of the Inversion Notices or

\footnotetext{
54. Lynnley Browning \& Saleha Mohsin, Treasury Corporate-Debt Rules Exceed Authority, Tax Lawyers Say, BLOOMBERG (July 15, 2016, 4:00 AM), http://www.bloomberg.com/news/articles/2016-07-15/treasury-corporate-debt-rules-exceedauthority-tax-lawyers-say.

55. While the Inversion Regulations apply to transactions entered into on or after April 4, 2016, the rules outlined in the Inversion Notice apply to transactions entered into on or after September 22, 2014 and the rules outlined in the Second Inversion Notice apply to transactions entered into on or after November 19, 2016.

56. Kelley Drye Client Advisory, Tax Inversions: Administrative and Legislative Responses, KELLEY DRYE \& WARREN LLP (Oct. 10, 2014), http://www.kelleydrye.com/publications/client_advisories/0930/_pdf/style=pdf/client_advisories_09 30.pdf.

57. Treas. Reg. § 1.6662-3 ("If any portion of an underpayment, as defined in section 6664(a) and $\$ 1.6664-2$, of any income tax imposed under subtitle A of the Internal Revenue Code that is required to be shown on a return is attributable to negligence or disregard of rules or regulations, there is added to the tax an amount equal to 20 percent of such portion.").
} 
Regulations until they file a return, and either sue for a refund or fail to comply with the Inversion Regulations and defend a suit of deficiency by the Internal Revenue Service ("IRS"). Once in court, the taxpayer would then have to be successful in its claim that Treasury exceeded its regulatory authority in issuing the Inversion Notices or Regulations.

Rather than openly defy the Inversion Notices and Regulations, some taxpayers found ways to circumvent them altogether and proceeded with their inversions despite the murky regulatory landscape. For example, Burger King completed its planned inversion by acquiring Canadian company Tim Hortons in December 2014, in part because the new foreign entity has far in excess of the twenty-five percent business activities in Canada necessary to prevent application of the inversion provisions under I.R.C. section $7874 .^{58}$ In January 2016, Johnson Controls announced plans to invert by merging with Ireland-based Tyco International Plc. ${ }^{59}$ In the Johnson Controls deal, shareholders of the existing U.S. companies were expected to own just shy of the sixty percent ownership threshold necessary to trigger the Inversion Notices and I.R.C. section $7874 .^{60}$

In one of the biggest inversion-related standoffs with Treasury, in November 2015, days after issuance of the Second Inversion Notice, Pfizer announced an over $\$ 150$ billion inversion deal with Ireland-based Allergan, the maker of Botox. ${ }^{61}$ Reportedly, Pfizer and Allergan knew that Treasury would come after them over the transaction, but had no idea that it would issue such far-reaching regulations that essentially gutted many of the planned financial benefits of the merger. ${ }^{62}$ In fact, in

58. The deal was projected to save Burger King approximately $\$ 275$ million in taxes between 2015 and 2018 according to Wall Street estimates. Kevin Drawbaugh, Burger King To Save Millions in U.S. Taxes in 'Inversion': Study, REUTERS (Dec. 11, 2014, 5:31 AM), http://www.reuters.com/article/2014/12/11/us-usa-tax-burgerking-idUSKBN0JP0CI20141211.

Notably, unlike some other potential U.S. corporate inverters, Burger King is already exempt from some of the restrictions because the combined Burger King/Tim Hortons enterprise has substantial Canadian operations. Richard Rubin, Burger King Deal Advances Amid U.S. Inversion Crackdown, BlOOMBERG (Sept. 23, 2014, 3:40 PM), http://www.bloomberg.com/news/articles/2014-09-23/lewtries-to-limit-tax-cut-deals-with-inversion-crackdown.

59. Andrew Sorkin, A Tidal Wave of Corporate Migrants Seeking (Tax) Shelter, N.Y. TIMES (Jan. 25, 2016), http://www.nytimes.com/2016/01/26/business/dealbook/a-tidal-wave-of-corporatemigrants-seeking-tax-shelter.html.

60. Id. ("[T]he Treasury Department implemented a rule that an American company could not complete an inversion if it owned more than 60 percent of the combined company; Johnson Controls will own 56 percent of the combined company.").

61. Jonathan D. Rockoff \& Dana Mattioli, Pfizer, Allergan Agree on Historic Merger Deal, WALL ST. J. (Nov. 22, 2015, 7:48 PM), http://www.wsj.com/articles/pfizer-allergan-on-cusp-ofmerger-deal-1448217490.

62. Michael J. de la Merced \& Leslie Picker, Pfizer and Allergan Are Said to End Merger as Tax Rules Tighten, N.Y. TIMES (Apr. 5, 2016), 
a clear victory for Treasury, within twenty-four hours of the issuance of the Inversion Regulations, Pfizer terminated the planned merger with Allergan, even though it had to pay a $\$ 400$ million break-up fee. ${ }^{63}$

Notwithstanding Treasury's "victory" over Pfizer, at least five other planned inversions remained on-track to close in $2016,{ }^{64}$ although all comply with the Inversion Regulations. ${ }^{65}$ The persistence of inversion deals, even in the face of the Inversion Regulations, underscores the necessity of congressional involvement for any permanent solution, should one be desired. ${ }^{66}$ In fact, when issuing the Inversion Regulations, Secretary Lew again implored Congress to tackle the inversion issue. ${ }^{67}$ As it impatiently waits for Congress to respond, Treasury has announced it will continue to expand its regulatory reach as far as possible in order to cast as large of a shadow as it can on these transactions, even if it is ultimately not able to stop them entirely. ${ }^{68}$

\section{THE MUSCLE BEHIND THE THREAT: TREASURY's BROAD REGULATORY POWERS}

In order to be valid, all agency issued regulations, including regulations issued by Treasury, must be promulgated pursuant to a

http://www.nytimes.com/2016/04/06/business/dealbook/tax-inversion-obama-treasury.html? r $=0$.

63. Jeffrey McCracken, Pfizer to Terminate $\$ 160$ Billion Merger With Allergan, BLOOMBERG (Apr. 5, 2016, 8:24 PM), http://www.bloomberg.com/news/articles/2016-04-06/pfizer-allergan-planto-mutually-end-merger-cnbc-reports.

64. Amy Thomson, Pfizer-Allergan's Tie-Up Isn't the Only Inversion in Town, BLOOMBERG (Apr. 5, 2016, 4:00 PM), http://www.bloomberg.com/news/articles/2016-04-05/pfizer-allergan-s-tieup-isn-t-the-only-inversion-in-town?nl=dealbook\&emc=edit_dlbkam_20160406.

65. For instance, by structuring to avoid triggering the thresholds for application of the inversion provisions.

66. Sorkin, supra note 59 ("By my count, based on a series of conversations with investment bankers, there are probably at least another dozen deals of meaningful size being negotiated in the pipeline. The question is what it will take for Congress to not only take notice, but to pass legislation to thwart this steady corporate migration.").

67. Press Release, U.S. Dep't of the Treasury, Remarks by Treasury Sec'y Jacob J. Lew on a Press Conference Call Regarding Announcement on Corporate Tax Inversions (Apr. 4, 2016) [hereinafter Press Release, Remarks by Treasury] ("Congress should not wait to act as inversions continue to erode our tax base. Only congressional action can fully address inversion transactions, and I urge Congress to act this year."), https://www.treasury.gov/press-center/pressreleases/Pages/j10406.aspx. See also Press Release, U.S. Dep't of the Treasury, Fact Sheet: Additional Treasury Actions to Rein in Corporate Tax Inversions (Nov. 19, 2015), https://www.treasury.gov/press-center/press-releases/Pages/j10281.aspx ("Only legislation can decisively stop inversions.").

68. Press Release, Remarks by Treasury, supra note 67 ("We will continue to explore additional ways to limit inversions. But only new anti-inversion legislation can stop these transactions. Until that time, creative accountants and lawyers will continue to seek new ways for companies to move their tax residences overseas and avoid paying taxes here at home."). 
delegation of authority by Congress. ${ }^{69}$ I.R.C. section 7805 (a) grants Treasury broad regulatory powers by authorizing it to provide "all needful rules and regulations" necessary to enforce the Internal Revenue Code. Moreover, a great number of provisions in the Internal Revenue Code also contain specific grants of statutory authority for Treasury to issue corresponding regulations. ${ }^{70}$ Treasury regulations are generally presumed to carry the force of law if they implement the underlying statute in a reasonable manner. ${ }^{71}$ The Supreme Court has stated that this delegation of regulatory authority is necessary in order to ensure the rules are written by "masters of the subject," who are "responsible for putting the rules into effect." 72

Moreover, although Treasury regulations are now presumed to be prospective in application, ${ }^{73}$ under I.R.C. section 7805(b) Treasury can make any regulation effective as early as the date of a notice of intention to issue regulations (without any special cause) or if the regulation is intended to "prevent abuse," it may be retroactive to any date deemed necessary by Treasury. ${ }^{74}$ This gives Treasury latitude to issue binding regulations that are retroactive in nature before they have undergone notice and comment. Under the Administrative Procedure Act ("APA"), nonbinding proposed regulations are supposed to be issued pursuant to notice and comment and, after proper consideration of public input, final prospective binding regulations are issued. ${ }^{75}$ Treasury's specific statutory grant of retroactive authority, however, supersedes the APA's general regulatory requirements. ${ }^{76}$

69. City of Arlington v. F.C.C., 133 S. Ct. 1863, 1882 (2013).

70. See, e.g., I.R.C. § 301(e)(4) (Distributions of Property) ("The Secretary shall prescribe such regulations as may be necessary or appropriate to carry out the purposes of this subsection."); $\S$ 385(a) (Treatment of certain interests in corporations as stock or indebtedness) ("The Secretary is authorized to prescribe such regulations as may be necessary or appropriate to determine whether an interest in a corporation is to be treated for purposes of this title as stock or indebtedness (or as in part stock and in part indebtedness)."); § 1092(c)(4)(H) (Exception for certain straddles) ("The Secretary shall prescribe such regulations as may be necessary or appropriate to carry out the purposes of this paragraph. Such regulations may include modifications to the provisions of this paragraph which are appropriate to take account of changes in the practices of option exchanges or to prevent the use of options for tax avoidance purposes.").

71. Nat'l Muffler Dealers Ass'n, Inc. v. United States, 440 U.S. 472, $476-77$ (1979).

72. Id. at 477 (citing United States v. Moore, 95 U.S. 760, 763 (1878)).

73. Prior to the passage of I.R.C. $\S 7805$ in 1996, all Treasury regulations could apply to transactions executed prior to their enactment, subject to "abuse of discretion."

74. Congress did not define "abuse" thus leaving open the question of whether Treasury is also able to unilaterally decide when "abuse" is occurring. See generally, Shannon Weeks McCormack, Tax Abuse According to Whom?, 15 FLA. TAX REV. 1 (2013).

75. See 5 U.S.C.S. $\S 553($ b)-(c) (2016).

76. See, e.g., Morton v. Mancari, 417 U.S. 535, 550-51 (1974) ("Where there is no clear intention otherwise, a specific statute will not be controlled or nullified by a general one, regardless 
Thus, Treasury's broad regulatory powers strengthen its power to wield a threat of law in two ways. First, because Congress has explicitly given Treasury broad general regulatory powers under I.R.C. section 7805(a), even when Congress has not enacted a specific delegation of authority to Treasury with respect to a tax statute, Treasury is often nevertheless able to issue legally binding regulations. For analytical purposes, the question then is not typically whether Treasury has authority to regulate a specific matter, but rather what the proper scope of the authority should be.

Most of Treasury's regulations derive their authority from the general delegation under I.R.C. section $7805 .^{77}$ Moreover, even if a specific delegation exists with respect to a particular topic, that authority is merely in addition to, and not in lieu of, the general regulatory authority granted to Treasury under I.R.C. section $7805{ }^{78}$ With respect to the Inversion Notices and Regulations, Congress has explicitly given Treasury broad regulatory authority under I.R.C. section $7874 .^{79}$ Because Congress has explicitly handed over significant rulemaking power to Treasury, the line between overreaching by Treasury and a legitimate delegation of authority by Congress is blurry at best. This makes it much more difficult for a taxpayer to determine ex ante whether it will be able to mount a successful legal claim that Treasury has overstepped its regulatory limits. If taxpayers are truly unclear about the legitimacy of their legal challenges, rather than engage in protracted and expensive litigation with the IRS, they may choose to simply comply with (or structure around) the dubious regulation. ${ }^{80}$

of the priority of enactment.").

77. Blanchard, supra note 18 , at 5 .

78. Id.

79. I.R.C. $\S 7874(\mathrm{~g})$ (“The Secretary shall provide such regulations as are necessary to carry out this section, including regulations providing for such adjustments to the application of this section as are necessary to prevent the avoidance of the purposes of this section, including the avoidance of such purposes through - (1) the use of related persons, pass-through or other noncorporate entities, or other intermediaries, or (2) transactions designed to have persons cease to be (or not become) members of expanded affiliated groups or related persons.").

80. Interestingly, in August of 2016, not taxpayers, but rather the United States Chamber of Commerce and the Texas Association of Business, filed a lawsuit against the IRS challenging the validity of the temporary Inversion Regulations issued in April of 2016. Complaint at 1, Chamber of Commerce v. I.R.S., No. 1:16-cv-944, W.D. Tex. (Aug. 4, 2016), http://www.chamberlitigation.com/sites/default/files/cases/files/16161616/Complaint\%20$\% 20$ Chamber\%20of\%20Commerce\%20v.\%20IRS\%20\%28USDC\%20-

$\% 20$ Western\%20District\%20of\%20Texas\%29_0.pdf. It is unclear, however, if the suit will survive the anticipated procedural hurdles, such as the Anti-Injunction Act. See infra Part IV.A. See also Alison Bennett Lawsuit on IRS Inversion Rules May Be 'Fascinating' Battle, BLOOMBERG BNA (Aug. 11, 2016), https://www.bna.com/lawsuit-irs-inversion-n73014446237/. 
Second, because I.R.C. section 7805(b) allows Treasury to backdate regulations retroactively to the date "on which any notice substantially describing the expected contents of any temporary, proposed, or final regulation is issued to the public," Treasury is able to easily engage in retroactive rule making through the use of notices. Indeed, both of the Inversion Notices explicitly provide that any regulations issued pursuant to the notices will be made retroactive to the date of the respective notices. ${ }^{81}$ As a result, Treasury is able to strengthen its threat of law because although a notice itself may not carry with it the force of law, to the extent that it substantially describes regulations that are intended to be issued at some future date, the notice is imbued with a pseudo force of law. Taxpayers must in many ways treat a notice with increased deference because at some future date, if final regulations described in the notice are issued, the full legal force of those regulations may be retroactive to the notice date. Treasury's ability to threaten a retroactively effective force of law compels taxpayers to comply with regulations described in a notice in the same way as they would a duly issued final regulation, because ultimately the penalty, audit, and litigation risks may be similar. ${ }^{82}$

\section{CONFRONTING THE THREAT: JUDICIAL LIMITATIONS TO Challenging TREasury's ABuse OF POWER}

With respect to most administrative agencies, if an affected constituent is displeased with a proposed regulation, it has the right to bring a pre-enforcement action against the agency the day the regulation is promulgated. ${ }^{83}$ APA section 704 provides plaintiffs "a cause of action to challenge 'final agency action,' which includes issuing temporary as well as final regulations", and APA section 702 "waives sovereign immunity for actions seeking relief 'other than money damages' for any 'person suffering legal wrong because of agency action, or adversely affected or aggrieved by agency action within the meaning of a relevant

81. 2014-42 I.R.B. 712; 2015-49 I.R.B. 775.

82. See infra discussions in Part IV.

83. Kristin E. Hickman, A Problem of Remedy: Responding to Treasury's (Lack of) Compliance with Administrative Procedure Act Rulemaking Requirements, 76 GEO. WASH. L. REV. 1153, 1162 (2008) (citing James T. O’Reilly, AdMinistrative RULEMAKING $§ 13: 1$ (2d ed. 2007) ("Pre-enforcement injunction actions sometimes are begun the very day that an agency rule is promulgated, with a request that the implementation of the rule be enjoined and that the court stay the effective date of the rule pending outcome of the litigation.")); Richard J. Pierce, Jr. et al., ADMINISTRATIVE LAW AND PROCESS § 5.7.4. (4th ed. 2004) ("In many circumstances, however, a party displeased with a regulation would prefer to wait and to challenge all aspects of that regulation in a proceeding in which that regulation is applied."). 
statute." " 94 The Supreme Court held in Abbott Labs. v. Gardner ${ }^{85}$ that a plaintiff has standing prior to the enforcement of a regulation by an agency in instances where the plaintiff is the subject of the regulation and risks penalties if it fails to comply. Since Abbott, courts have regularly allowed judicial review of pre-enforcement regulatory actions in a variety of circumstances. ${ }^{86}$

However, because the specific statutory standing rules under I.R.C. section 7421 and the Declaratory Judgment Act ("DJA") ${ }^{87}$ applicable to tax cases supersede the APA, pre-enforcement judicial review of Treasury's regulatory actions is extremely difficult and uncommon. ${ }^{88}$ Moreover, even if a taxpayer survives I.R.C. section 7421 and DJA challenges, there would remain significant hurdles in the Article III justiciability doctrines to overcome. As a result, most challenges to Treasury regulations occur in one of two postures. The first is in refund litigation, where a taxpayer has paid the applicable taxes and penalties owed pursuant to the challenged regulation and then sues for a refund. The second is when after reviewing the taxpayer's filings the IRS assesses a deficiency against a taxpayer for failing to follow the challenged regulation, and the taxpayer challenges the deficiency.

\section{A. Section 7421 and the Declaratory Judgment Act}

I.R.C. section 7421 (also known as the "Anti-Injunction Act") provides that, subject to limited exceptions, "no suit for the purpose of restraining the assessment or collection of any tax shall be maintained in any court by any person, whether or not such person is the person against whom such tax was assessed." 89 This rule has been interpreted broadly to apply not only to the "assessment or collection" of taxes, but also to any activities that have the potential to or are intended to lead to the

84. Hickman, supra note 83, at 1162-63.

85. Abbott Labs. v. Gardner, 387 U.S. 136, 154 (1967).

86. Hickman, supra note 83, at 1163.

87. 28 U.S.C.S. $\S 2201(2000)$.

88. Hickman, supra note 83 , at 1174 ("In other words, consistent with scholarly expectations, the limitations posed by I.R.C. $\S 7421$, the DJA, and judicial interpretations thereof have created a climate that simply disfavors allowing courts to remedy legal wrongs in the tax context through preenforcement review. Thus, in this climate, even where courts might be inclined to interpret I.R.C. $\S$ 7421 and the DJA to allow pre-enforcement APA procedural challenges against Treasury regulations to proceed, they may nevertheless decline jurisdiction on other more general grounds.").

89. I.R.C. § 7421 contains limited procedural and substantive exceptions. Hickman, supra note 83 , at 1165 (For example, judicial review is permitted if the IRS fails to send a notice of deficiency prior to collection or if a taxpayer is seeking a determination of whether he or she is an employee for employment tax purposes). 
assessment or collection of taxes. ${ }^{90}$ It has also been held to apply with respect to constitutional claims. ${ }^{91}$ Likewise, the DJA provides that courts are prohibited from issuing declaratory judgments "with respect to Federal taxes," with limited exceptions. ${ }^{92}$ Courts have routinely held that the DJA and I.R.C. section 7421 are coextensive. ${ }^{93}$

Although the legislative history is sparse, in Enochs v. Williams Packing \& Navig. Co., the Supreme Court announced that the "manifest purpose of [I.R.C. section] 7421(a) is to permit the United States to assess and collect taxes alleged to be due without judicial intervention, and to require that the legal right to the disputed sums be determined in a suit for refund" in order to ensure "the United States is assured of prompt collection of its lawful revenue." It further held that only if it is "apparent that, under the most liberal view of the law and the facts, the United States cannot establish its claim," and "the taxpayer would suffer irreparable injury if collection were effected" may a suit for an injunction be maintained. ${ }^{95}$ The Court further emphasized that " $[\mathrm{t}] \mathrm{o}$ require more than good faith on the part of the Government would unduly interfere with a collateral objective of the [Anti-Injunction] Act — protection of the collector from litigation pending a suit for refund."

Thus, even under this so-called "Williams Packing exception," courts are only permitted to consider a pre-enforcement review if both the requirements of no colorable claim and irreparable injury are satisfied. ${ }^{97}$ Importantly, under the second requirement, courts have consistently held that taxpayers' claims of irreparable harm are undermined by the fact they can pay the tax and sue for refund. ${ }^{98}$ Accordingly, even if Treasury completely disregarded the express provisions of the Code and had little

90. For these purposes pre-enforcement review has also been denied with respect to the collection of penalties, which were held to be part of the "tax" under $\S 7421$. See, e.g., Mobile Republican Assembly v. United States, 353 F.3d 1357, 1362 (11th Cir. 2003).

91. See, e.g., Alexander v. 'Americans United' Inc., 416 U.S. 752, 759 (1974) (“[D]ecisions of this Court make it unmistakably clear that the constitutional nature of a taxpayer's claim ... is of no consequence under the Anti-Injunction Act.").

92. 28 U.S.C. § 2201(a) (2016). Exceptions include certain declaratory judgments in bankruptcy and for qualification of tax-exempt status.

93. Hickman, supra note 83, at 1166. See, e.g., Ambort v. United States, 392 F.3d 1138, 1140 (10th Cir. 2004); Sigmon Coal Co. v. Apfel, 226 F.3d 291, 300-01 (4th Cir. 2000).

94. 370 U.S. 1,7 (1962).

95. $I d$.

96. Id. at $7-8$.

97. Hickman, supra note 83, at 1170-1. See, e.g., Alexander v. 'Americans United' Inc., 416 U.S. 752,758 (1974).

98. Hickman, supra note 83, at 1171. See, e.g., United States v. Am. Friends Serv. Comm. et al., 419 U.S. 7, 11 (1974). 
to no factual basis for its actions, under the second prong a taxpayer still would have a nearly impossible case for gaining pre-enforcement relief. ${ }^{99}$

\section{B. Justiciability Limitations}

Even if a taxpayer survives I.R.C. section 7421 and DJA challenges, there would remain significant hurdles in the Article III justiciability doctrines to overcome. Because most pre-enforcement cases are blocked by I.R.C. section 7421 and the DJA, courts rarely deal with the more general issues of standing and ripeness as they relate to Treasury regulations: "Nevertheless, several judicial opinions that do tread such ground reinforce the unavailability of pre-enforcement judicial review for Treasury regulations by accepting what appears to be a more restrictive view of standing or ripeness doctrine in tax cases as opposed to other areas of administrative law." 100

Article III requires that a taxpayer satisfy the basic case or controversy standing requirements. ${ }^{101}$ If a taxpayer is merely subject to a notice and Treasury has not issued any actual regulations yet, then clearly ripeness and finality doctrines are problematic for the taxpayer. ${ }^{102}$ Moreover, at a minimum to have standing in compliance with Article III, the plaintiff must have suffered an injury in fact, there must be a causal relationship between the harm and the complained action, and it must be likely that the injury can be redressed by a favorable decision. ${ }^{103}$ With respect to the Inversion Notices, and even the Inversion Regulations, Article III's "injury in fact" requirements pose a significant hurdle for taxpayers wanting to bring a direct APA challenge without having to engage in a transaction to which the regulations would apply. ${ }^{104}$

99. In Nat'l Fed'n of Indep. Bus. v. Sebelius, the Supreme Court did find I.R.C. § 7421 did not prevent the constitutional challenge of the patient mandate in the Patient Protection and Affordable Care Act because the shared patient responsibility constitutes a penalty, and not a tax, for purposes of the statute. 132 S. Ct. 2566, 2583-84 (2012).

100. Hickman, supra note 83, at 1174.

101. Lujan v. Defenders of Wildlife, 504 U.S. 555, 560 (1992) ("One of those landmarks, setting apart the 'Cases' and 'Controversies' that are of the justiciable sort referred to in Article III'serv[ing] to identify those disputes which are appropriately resolved through the judicial process,'-is the doctrine of standing. Though some of its elements express merely prudential considerations that are part of judicial self-government, the core component of standing is an essential and unchanging part of the case-or-controversy requirement of Article III.") (internal citations omitted).

102. See Cohen v. United States, 578 F.3d 1, 7, 14 (D.C. Cir. 2009).

103. Lujan, 504 U.S. at 560-61 (internal citations omitted).

104. Patrick J. Smith, Standing Issues in Direct APA Challenges to Tax Regulations, 149 TAX NOTES 1033, 1037 (Nov. 23, 2015) ("The government will most likely rely on the injury-in-fact requirement in arguing that taxpayers bringing direct APA challenges to tax regulations in district 
The obvious problem with respect to the Inversion Notices and Regulations is that a corporation would actually need to invert in order to truly test the provisions. Inversion is not an action that can be readily undone. Before the corporation spends the considerable time and resources necessary to execute such a transaction, they would want to have some certainty as to how the corporation would be taxed going forward. Indeed, tax considerations in many instances are a primary driver of the inversion structures. Thus in order for taxpayers to gain clarity on the legality of the regulations ex ante, they will need to argue that they are in fact harmed by being forced to refrain from the transaction because of the potential threat of dubious regulations. ${ }^{105}$

\section{Deference and Mayo's "End" of Tax Exceptionalism}

If a taxpayer is able to challenge Treasury regulations in court, what deference will they be afforded? In Mayo Foundation, the Supreme Court found that Chevron and Mead provide the appropriate framework for analyzing Treasury's rulemaking authority and rejected tax exceptionalism. $^{106}$ Historically, Treasury maintained a special administrative status and repeatedly stretched the bounds of its power to issue general and interpretive authority regulations and bypass requirements under the APA. Congress itself has expressly given Treasury the ability to use temporary and retroactive regulations. Notwithstanding the Mayo Foundation decision, Treasury's recent responses to the proliferation of corporate tax inversions have again resurrected its claim for tax exceptionalism.

As a general matter, agency rules are entitled to either strong deference under Chevron, U.S.A., Inc. v. Natural Resources Defense Council, Inc. ${ }^{107}$ if the agency's actions satisfy both prongs of the two-

\footnotetext{
court lack standing if they have not engaged in at least one transaction to which the challenged regulation would apply. The reasoning would be that the challenger has not suffered an injury in fact as a result of the issuance of the regulations. According to the [Lujan] Court, an injury must be actual or imminent - not conjectural or hypothetical - to satisfy the injury-in-fact requirement for standing. The government will likely argue that any injury suffered by a taxpayer that has not engaged in a transaction to which the regulations would apply is only conjectural or hypothetical.").

105. Id. at 1037-38 ("The taxpayer's counterargument would be that a party can be an object of regulations without having actually engaged in a transaction to which they would apply. The reasoning would be that the regulations have harmed the taxpayer by making it less desirable and less advantageous to engage in the type of transaction to which the regulations would apply and that, in the absence of the adverse tax consequences, the taxpayer clearly would have engaged in it. In other words, the taxpayer is harmed by the challenged regulations because it is refraining from that transaction.").

106. 562 U.S. $44,52-60$ (2011).

107. 467 U.S. 837,844 (1984). Chevron first asks whether "Congress has directly spoken to the
} 
step test set forth in United States v. Mead Corp. ${ }^{108}$, or are otherwise entitled to the lesser sliding-scale deference of Skidmore v. Swift \& Co. ${ }^{109}$ However, prior to Mayo, courts found that in many cases tax regulations should be treated differently, providing a basis for so-called tax exceptionalism. In particular, many argued that while Chevron deference was available for Treasury regulations issued pursuant to specific grants of congressional authority, the lesser deference of National Muffler Dealers Ass'n, Inc. v. United States ${ }^{110}$ applied when Treasury exercised its regulatory powers under general grants of authority, such as that in I.R.C. section 7805(a), authorizing Treasury to issue "all needful rules and regulations." 111

In Mayo, the Supreme Court definitively held that tax is not special and absent a "justification to do so" Treasury regulations should be analyzed under the same framework used by all other areas of administrative law. ${ }^{112}$ The Court stated that it is "not inclined to carve out an approach to administrative review good for tax law only. To the contrary, [it has] expressly ' $[\mathrm{r}]$ ecogniz[ed] the importance of maintaining a uniform approach to judicial review of administrative action." "113 It further held that all Treasury regulations that satisfy Mead are Chevron-

precise question at issue" or whether Congress left an ambiguity. Id. at 842. In the latter case, a court should uphold that agency's interpretation so long as it is a "permissible construction" that is not "arbitrary, capricious or manifestly contrary to the statute." Id. at 843-44.

108. 533 U.S. 218, 226-27 (2001). Under Mead, the court must first ask whether Congress "delegated authority to the agency ... to make rules carrying the force of the law," and then ask whether the regulation is "promulgated in the exercise of th[e] authority." Id.

109. 323 U.S. 134, 140 (1944). Under Skidmore, the level of deference given to agency action should "depend upon the thoroughness evident in its consideration, the validity of its reasoning, its consistency with earlier and later pronouncements, and all those factors which give it power to persuade, if lacking power to control." Id. Note that there are many permutations to the implementation and contours of this standard in administrative law jurisprudence, but this is an articulation of the general rule.

110. 440 U.S. 472, 477 (1979) ("In determining whether a particular regulation carries out the congressional mandate in a proper manner, we look to see whether the regulation harmonizes with the plain language of the statute, its origin, and its purpose. A regulation may have particular force if it is a substantially contemporaneous construction of the statute by those presumed to have been aware of congressional intent. If the regulation dates from a later period, the manner in which it evolved merits inquiry. Other relevant considerations are the length of time the regulation has been in effect, the reliance placed on it, the consistency of the commissioner's interpretation, and the degree of scrutiny Congress has devoted to the regulation during subsequent re-enactments of the statute.").

111. See Rowan Cos., Inc. v. United States, 452 U.S. 247, 253 (1981); United States v. Vogel Fertilizer Co., 455 U.S. 16, 24 (1982) (although Rowan and Vogel pre-date Chevron and Mead, the latter two cases were not tax-specific).

112. Mayo Found. for Med. Educ. and Research v. United States, 562 U.S. 44, 55 (2011); see also United States v. Home Concrete \& Supply, LLC, 132 S. Ct. 1836, 1847 (2012).

113. Mayo Found., 562 U.S. at 55. 
eligible. ${ }^{114}$ Specifically, it rejected any distinction between specific and general grants of authority and made clear that even if Treasury exercises its regulatory powers under general grants of authority, such as that in I.R.C. section 7805(a), as long as they are issued pursuant to notice and comment, they should be eligible for Chevron deference. ${ }^{115}$

A second potentially less Treasury-favorable implication of Mayo is that Treasury may no longer be able to claim, as it historically has done, that the vast majority of its tax regulations are simply exempt from APA requirements. Historically, Treasury has maintained that most of its rules promulgated under general grants of authority are not legislative rules subject to the notice and comment rulemaking requirements of APA sections 553(b) and (c). ${ }^{116}$ Rather, Treasury argues that these rules satisfy one of the interpretative rule, procedural rule, or good cause exceptions from those procedures. ${ }^{117}$ However, the Court in Mayo, at least with respect to judicial review, eliminated the difference between Treasury's regulations issued under grants of specific versus general grants of authority. ${ }^{118}$ Thus, to the extent that Mayo more broadly ended tax exceptionalism, Treasury may have even shakier ground to claim that its regulations are somehow special and therefore exempt from the

114. Id. at 57 ("We believe Chevron and Mead, rather than National Muffler and Rowan, provide the appropriate framework for evaluating [tax regulations].").

115. Id. at 56-58 ("We have held that Chevron deference is appropriate "when it appears that Congress has delegated authority to the agency generally to make rules carrying the force of law, and that the agency interpretation claiming deference was promulgated in the exercise of that authority.' Our inquiry in that regard does not turn on whether Congress's delegation of authority was general or specific.... The Department issued the full-time employee rule only after noticeand-comment procedures, again a consideration identified in our precedents as a 'significant' sign that a rule merits Chevron deference." (internal citations omitted)).

116. Hickman, supra note 83, at 1157-58.

117. Id. at 1159 ("At a minimum, the tax community has always understood that Treasury regulations promulgated pursuant to specific grants of authority in substantive I.R.C. provisions are legislative in character. Yet, Treasury often fails to follow APA rulemaking requirements even when it issues regulations pursuant to such authority. On those infrequent occasions when Treasury makes an explicit claim to the good cause exception, Treasury rarely offers the sort of particularized explanation often demanded by the courts.").

118. In Altera Corp. v. Comm'r, the Tax Court invalidated regulations under I.R.C. section 482 that were issued in 2003 on the procedural grounds that the IRS did not provide sufficient explanation for its rulemaking. 145 T.C. No. 3 (July 27, 2015). Even prior to Mayo and Altera, Kristin Hickman persuasively argued that, "[Treasury's] position is generally implausible under modern conceptions of the distinction between legislative and interpretative rules, murky as that doctrine is." Hickman, supra note 83, at 1158; see also Kristin E. Hickman, Coloring Outside the Lines: Examining Treasury's (Lack of) Compliance with Administrative Procedure Act Rulemaking Requirements, 82 NOTRE DAME L. REV. 1727, 1740-59 (2007) (documenting methodology and findings of study of 232 regulatory projects for which Treasury published notices of proposed rulemaking, temporary regulations, or final regulations in the Federal Register between January 1, 2003, and December 31, 2005). 
general APA rules that other administrative agencies must comply with. ${ }^{119}$

Even if it is true that Treasury can no longer claim broad exemption, compliance with APA notice and comment by itself does not guarantee that more taxpayer friendly regulations will ensue. This is particularly true with respect to issues about which Treasury feels strongly and with respect to issues affecting disparate taxpayers with no common lobbying efforts. In fact, in order to make sure it avails itself of Chevron eligibility, Treasury may more strategically engage in notice and comment procedures, as it did with the Inversion Notices, particularly when it believes it is acting on shaky legal ground. Not only will Treasury have a strong argument that the Mead requirements are satisfied, as discussed above, increasing notice can actually extend Treasury's ability to issue retroactive regulations. ${ }^{120}$

\section{What is a Taxpayer Left to Do?}

Because most pre-enforcement judicial review actions would likely be barred under I.R.C. section 7421 and the DJA, any remaining cases would have a tough time overcoming Article III standing and ripeness limitations, and once in court Treasury would likely enjoy Chevron deference, what other options does a taxpayer have in the face of questionable Treasury regulations? A taxpayer is left with a few choices, none of them arguably as ideal as pre-enforcement review.

First, a taxpayer may sue for refund. However, this response is not an option if the taxpayer lacks the financial resources to pay the resulting tax or if the taxpayer does not want to suffer the economic burdens that would ensue if a court upholds Treasury's actions. For example, in the case of the Inversion Notices or Regulations, if a taxpayer engages in an inversion transaction, it must "overpay" its taxes by failing to claim any of the purported benefits from the inversion and then sue for a refund and hope those monies are recovered. Second, a taxpayer may act in contravention to Treasury's rules and claim the benefits on its return and wait for a notice of deficiency from the IRS. However, this requires the taxpayer to subject itself to understatement penalties and closer scrutiny

119. See Leslie Book, A New Paradigm for IRS Guidance: Ensuring Input and Enhancing Participation, 12 FLA. TAX REV. 517, 550 (2012) ("As Mayo did not speak to that issue precisely, it remains to be seen how the tax bar's exceptional approach to public participation will fare.").

120. This phenomenon, although statutorily permissible under I.R.C. section 7805(b)(3), is in direct contravention of typical APA procedures that require final regulations to be issued prospectively following the required notice and comment period. 
of its entire return. ${ }^{121}$ Moreover, the taxpayer has to wait for the IRS to act before it is able to bring its case to court. Third, even if a taxpayer engages in a transaction not in compliance with Treasury's guidance, it may choose to seek pre-litigation settlement with the IRS. While a taxpayer has the potential to gain more favorable terms in the settlement than it would in court, the outcome is largely out of the control of the taxpayer's hands and the process is not able to create binding precedent on the IRS to the extent the underlying substantive issue is recurring.

As a result of the lack of any favorable choices, in many cases, the easiest option is for taxpayers to merely comply with the dubious Treasury action, even if they believe it involves an unlawful exercise of Treasury's powers. Otherwise taxpayers will "put themselves through the effort of raising a challenge, placing themselves in a negative enforcement position or operating indefinitely in a state of uncertainty regarding tax noncompliance and the potential consequences." 122

\section{PRACTICAl Implications of the Threat OF LAW}

In this Article, I argue that when Treasury acts under the guise of authority, when it is unclear or doubtful it actually possesses the legal authority to do so, it is able to effectively exert over taxpayers a threat of law. Whether or not this type of threat is desirable or legally defensible, ${ }^{123}$ it can nevertheless be an effective tool for Treasury because taxpayers often cave in or otherwise modify their behavior in response.

\section{A. The Full Force of the Threat of Law}

Even highly sophisticated taxpayers with ample available resources to fight Treasury are keenly aware of the inevitable uphill battle they must face. As discussed above, in the first instance, taxpayers face significant challenges to obtaining pre-enforcement review of even the most questionable Treasury actions under I.R.C. section 7421 and the

121. Negligence or Disregard of Rules of Regulations, 26 C.F.R. § 1.6662-3 (2016).

122. Hickman, supra note 83, at 1182 ("Many taxpayers undoubtedly elect to comply with or rearrange their affairs to avoid regulations that they find questionable ...").

123. See, e.g., Wu, supra note 3, at 1854 ("Beyond this basic division, several other areas can be identified in which threats may constitute an abuse, as opposed to a useful tool. The first is when an agency uses threats to take actions that Congress has specifically barred, or to accomplish objectives for which it would otherwise lack delegated authority."). See also Noah, supra note 3, at 895 (discussing how the Federal Reserve Board "imposed conditions on (or extracted voluntary commitments from) applicants that appear to conflict with limits of its statutory authority."). 
DJA. This lack of a readily available ex ante judicial remedy then leaves taxpayers left to choose among the less ideal ex post options. In some instances they may continue with their planned transactions, if possible, and then challenge the government after the fact through either a suit for refund or challenge to a notice of deficiency. However, as discussed above, both of these options subject the taxpayer to any number of undesirable consequences, including exposure to significant financial uncertainty, steep litigation costs, and potential understatement penalties. As a result, many taxpayers simply choose the option of least resistance and greater certainty by merely giving in to Treasury's threat of law, even if they strongly disagree with the legitimacy of Treasury's power. ${ }^{124}$

Treasury's threat of power, legitimate or not, is buttressed by statutory advantages it enjoys and by the Supreme Court's decision in Mayo. I.R.C. section 7805(b) explicitly gives Treasury the authority to issue regulations retroactive to the date any notice substantially describing the expected contents of any temporary, proposed, or final regulation is issued to the public. This bolsters the threat in several regards. First, even if a notice itself is not binding on taxpayers, it creates a threat of law that can nevertheless create the effect of the force of law because of the retroactivity. The final regulations once issued, carry the force of law until successfully challenged by the taxpayer, and failure to comply with the regulations will subject taxpayers to the imposition of understatement penalties. ${ }^{125}$ As a result, even a nonbinding notice of intention to issue regulations can itself be immediately binding in a practical sense, because the contents therein will one day become binding retroactively once regulations are in fact issued.

If a taxpayer does choose to challenge Treasury's actions in court, Mayo has guaranteed that Treasury's actions will be eligible for the more deferential Chevron standard, as opposed to the more taxpayer-favorable National Muffler standard, regardless of whether Treasury is acting under a specific or general statutory grant of authority, particularly if it allows for a notice and comment period. Moreover, even if the regulation itself is struck down, the court can still respect Treasury's substantive interpretation of the law as reasonable and the taxpayer may still lose on

124. Indeed, as noted above, although taxpayers have been severely impacted by the regulations, it was the United States Chamber of Commerce and the Texas Association of Business that filed a lawsuit against the IRS challenging the validity of the temporary Inversion Regulations. See supra note 80 and accompanying text.

125. 26 C.F.R. § 1.6662-3(a) ("If any portion of an underpayment, as defined in section 6664(a) and $\S 1.6664-2$, of any income tax imposed under subtitle A of the Internal Revenue Code that is required to be shown on a return is attributable to negligence or disregard of rules or regulations, there is added to the tax an amount equal to 20 percent of such portion."). 
the merits. ${ }^{126}$ Under National Cable \& Telecommunications Association v. Brand X Internet Services, any reasonable Treasury interpretation of an ambiguous statute can override the prior judicial interpretation of the statute if Treasury's interpretation passes Chevron. ${ }^{127}$ Combined these judicial doctrines create a significant hurdle for taxpayers challenging Treasury actions.

\section{B. Swift Responses to Taxpayer Abuse}

If left largely unchecked by the judicial system, should this broad threat of power by a regulatory agency otherwise be contained? In the face of aggressive taxpayer abuse, Treasury's ability to act swiftly to curb taxpayer behavior may be desirable, particularly when Congress is unable or unwilling to do so. ${ }^{128}$ Attempting to stay one-step ahead of wily taxpayers is nearly an impossible task, and so creating uncertainty for taxpayers, either through broad anti-abuse doctrines or other measures may be the only effective way to deter abusive transactions. ${ }^{129}$

Taxpayers are already subject to challenge by the IRS on transactions that have already closed if the transactions lack economic substance and have no underlying business purpose other than the realization of tax benefits. ${ }^{130}$ If a transaction fails to satisfy these rules, the purported tax benefits of the transaction can be retroactively stripped if successfully challenged in court. While the economic substance doctrine may be an invaluable weapon in the IRS's arsenal against abusive transactions, it is unable to stop many of the complicated transactions devised by sophisticated taxpayers and their advisors ex ante. However, when combined with the threat of law, Treasury may

126. See Auer v. Robbins, 519 U.S. 452, 461 (1997); Bowles v. Seminole Rock \& Sand Co., 325 U.S. 410, 413-14 (1945).

127. 545 U.S. 967,982 (2005)

128. Blanchard, supra note 42, at 89 ("[The Inversion Notice was] rushed out in response to growing political insistence that something had to be done to stop the so-called tsunami of inversions supposedly taking place in recent months. Given the political deadlock in Congress, the executive and legislative branches appeared to be largely in agreement that for the time being, it was up to the IRS to take action-so it did."). See also Wu, supra note 3, at 1851 ("The greatest advantage of a threat regime is its speed and flexibility.").

129. See David A. Weisbach, Ten Truths About Tax Shelters, 55 TAX L. REv. 215, 249 (2002) (discussing the role uncertainty may play in deterring tax shelters).

130. Under long-standing case law principles, recently codified in part by I.R.C. section 7701(o), this threat against improper taxpayer behavior may not in substance really expand Treasury's otherwise existing powers. 26 U.S.C. $\$ 7701$ (o) (2012) (a "transaction shall be treated as having economic substance only if (A) the transaction changes in a meaningful way (apart from Federal income tax effects) the taxpayer's economic position, and (B) the taxpayer has a substantial purpose (apart from Federal income tax effects) for entering into such transaction.”). 
have a much more effective weapon to fight perceived tax abuses. A notice for retroactive regulations or the issuance of dubious proposed, temporary or final regulations may serve to broaden the already existing cloud under which taxpayers must operate. The threat of law will thus serve as a way to affect taxpayer behavior while waiting for Congress to take action, even if it does not have the authority to do so.

\section{A Solution for Congressional Inaction?}

The threat of law can be used to motivate an otherwise dormant or gridlocked Congress into timely passing, or at least considering, needed legislation. By changing the applicable default rules, unilateral action by an agency should propel Congress into action, particularly if it has overstepped its delegated authority and Congress disagrees with the actions the agency has taken. ${ }^{131}$ If Congress disagrees with the new default law, then timely and responsive legislation can be implemented to overturn it. It is likely that to the extent highly organized and/or sophisticated groups of taxpayers are adversely affected, the incentive for congressional members to act will be even greater. These affected taxpayers can bombard Congress with forceful lobbying efforts, putting significant pressure on them to strike down the offensive threat of law.

On the other hand, even if Congress agrees with the agency's new regulatory action, it may still need to codify the changes, particularly if the regulations were enacted under a questionable delegation of authority. While the pressure may not be as great on Congress to pass new legislation if the threat of law sufficiently changes the default rules, there are still reasons why Congress may feel compelled to act. If the new change in law is truly desirable, Congress may want to insulate it from any future legal challenges and/or expand it to make it more effective. ${ }^{132}$ Even more compellingly, if, as was the case with the

131. Shay, supra note 12, at 477 ("The obvious advantage of taking regulatory action is the ability to act quickly. That is especially important because more and more companies are planning or seeking transactions that take advantage of apparent statutory loopholes.... The exercise of regulatory authority changes the default position. Instead of waiting for Congress to act and relying on the market to deal with the risk of losing the corporate tax base in the meantime (in hopes there would be an inadequate supply of foreign targets or the price or risk of acquiring foreign targets goes too high), adopting regulations first would reduce the risk to the U.S. corporate tax base while Congress considers how to address the problem in legislation as part of tax reform or otherwise.").

132. Reuven S. Avi-Yonah \& Omri Marian, Inversions and Competiveness: Reflections in the Wake of Pfizer/Allergan, Mich. PuB. L. \& Legal Theory ReS. PAPER Sers. 9 (Dec. 14, 2015) ("Treasury's limited regulatory authority clearly establishes that the solution to inversions cannot come in a form of administrative notices."), https://poseidon01.ssrn.com/delivery.php?ID=8120980250880670901060730160670230730280460 
Inversion Notices and Regulations, the proposed provisions are revenue raisers, Congress will be able to capitalize on having additional revenue offsets for its budget planning purposes if the regulations are enacted as law. ${ }^{133}$

\section{Limitations on the Remedies for the Threat of Law}

Despite the potential benefits a threat of law may yield, the question remains, if taxpayers are not engaged in abusive transactions and Treasury has merely overstepped its regulatory authority, what limitations should the threat of law face? Given the difficult time taxpayers have seeking pre-enforcement judicial review of their grievances, sentiments of unfairness and lack of due process are certainly warranted. Indeed, even in Enochs, where the Supreme Court openly accepted the limitations imposed by I.R.C. section 7421, it stated a presumption that Treasury would be acting in "good faith." 134 To the extent that this assumption is no longer warranted, it seems that permitting a continued expansive application of I.R.C. section 7421 and the DJA to inhibit pre-enforcement review is no longer warranted. Rather, taxpayers must have some available avenue to challenge ex ante regulations resulting from an abuse of power.

If pre-enforcement judicial review is not feasible, taxpayers may also get relief through another avenue, although it has only been done once before. ${ }^{135}$ A final administrative rule can be overturned through the Congressional Review Act (the "CRA") as long as lawmakers in both houses of Congress are able to pass a "resolution of disapproval" and get the signature of the President (or have two-thirds majorities in both

810790030231090710151011190831001221141230111030480320101201110040690850290070120 960050760930390111010690691140210290670470610050840900890021071001141131070980810 $14105026071108026070125026024025087106085064 \&$ EXT=pdf.

133. Shay, supra note 12, at 477-78 ("The Stop Corporate Inversions Act of 2014 is estimated by the Joint Committee on Taxation to raise $\$ 19.5$ billion over 10 years. A regulatory change is not treated as raising revenue until revenue is received (that is, loss of revenue does not occur). It does not have the benefit of making available a revenue offset for Congress to use for an alternative purpose.").

134. Enochs v. Williams Packing \& Navigation Co., Inc., 370 U.S. 1, 7-8 (1962) ("[Section 7421(a)] indicates that if Congress had desired to make the availability of the injunctive remedy against the collection of federal taxes not lawfully due depend upon the adequacy of the legal remedy, it would have said so explicitly. Its failure to do so shows that such a suit may not be entertained merely because collection would cause an irreparable injury, such as the ruination of the taxpayer's enterprise.")

135. The Congressional Review Act followed the election of George W. Bush and was passed to overturn a regulation issued late in President Bill Clinton's last term which required new ergonomic rules for office workers. 
houses). ${ }^{136}$ This is not an adequate remedy for taxpayers subject to Treasury overreaching for several reasons. First, the CRA requires the same level of congressional support that it would require to simply pass tax legislation overruling the offending regulation. It also requires that the President reject Treasury's use of regulatory power. In the case where the President supports Treasury's use of power, particularly where Congress is unable or unwilling to act, regulations with the threat of law may end up standing absent contrary support from a super-majority of Congress.

Ultimately, absent an enhanced access to pre-enforcement judicial review or a diminished standard of review for examining Treasury's exercises of a threat of law, current remedies for taxpayers affected by Treasury's overreaching regulatory actions, such as those in the Inversion Notices and Regulations, may be insufficient. While the need for Treasury to be able to respond swiftly to actual taxpayer abuses may be helpful, and at times necessary, exceeding the bounds of its regulatory authority cannot be the accepted solution.

\section{CONCLUSION}

While it is clear that even a threat of law can have a chilling effect on taxpayers, when adequate statutory authority does not exist, ultimately it can not be a permanent substitute for legislative action. Presumably, regulated entities should be more willing to actively defy a dubious exercise of regulatory authority, particularly when they sense an impotent Congress that is unable or unwilling to address the underlying issue. However, in many cases the stakes for the regulatees are too high.

Given the difficulties taxpayers face in challenging an improper threat of law by Treasury ex ante through traditional channels, such as the courts, it becomes extremely important that there are ways in which Treasury is restricted from acting in defiance of its statutory authority. Procedural and/or judicial safeguards must be put in place in order to ensure there are adequate checks and balances on perceived abuses of Treasury's powers. One potential solution would be a more narrow application of I.R.C. section 7421 and the DJA. Moreover, to the extent that Congress more regularly and timely engages in substantive law making, administrative agencies will have fewer opportunities to engage in overreaching, quasi-legislative rulemaking.

136. 5 U.S.C. $\S \S 801-08$ (2006). 